\title{
EVOLUTION OF BRAZILIAN ELDERLY WITH HIP FRACTURE SECONDARY TO A FALL
}

\author{
Rosamaria Garcia, Mariana Deckers Leme, Luiz Eugênio Garcez-Leme
}

Garcia R, Leme MD, Garcez-Leme LE. Evolution of brazilian elderly with hip fracture secondary to a fall. Clinics. 2006;61(6):539-44.

OBJECTIVE: To contribute to fall prevention by studying the epidemiological profile, mortality, and functional evolution of elderly persons with hip fracture, in Brazil, in the year following a fracture.

METHOD: Fifty-six elderly patients aged 60 years and over with hip fracture secondary to a fall and admitted in 2000 were included. In addition to the medical record data, patients or their guardians filled a form providing information regarding personal data, history of fall and fracture, physical evaluation, and ability to perform basic and instrumental activities of daily living prior to and 1 year after their fracture, using Katz's Index and Lawton's Index, respectively.

RESULTS: Fractures were more common among Caucasian widowed women, and most falls occurred at home. General mortality within 1 year after the occurrence of fracture was $30.35 \%$ and was associated with sex and age. There was an increase in the inability to walk and in the use of a supporting device. A significant reduction in the functional ability to perform basic and instrumental activities of daily living was found.

CONCLUSION: The evolution of hip fracture in the year following it is related to high mortality and to a decrease in functional ability, with age and male sex being the factors associated with a worse prognosis, emphasizing the need for special follow-up care of these groups during the immediate and late postoperative periods.

KEYWORDS: Elderly. Hip fracture. Fall. Functional ability. ADLs.

\section{INTRODUCTION}

The rapid growth of the elderly population has resulted in a proportional rise in the number of elderly individuals with chronic disability during this phase of life. Chronic disability directly interferes with the quality of life of the elderly, since it changes their way of living and their health conditions.

Falls are a serious public health problem among the elderly because of their frequency, morbidity, and out-ofpocket and public health-care expenses, ${ }^{1}$ in addition to the stress experienced by caregivers. ${ }^{2}$ In association with os-

Department of Orthopedics and Traumatology, Orthogeriatric Group, São Paulo University Medical School - São Paulo/SP, Brazil.

Department of Preventive Medicine, São Paulo University Medical School São Paulo/SP, Brazil.

Email: lueglem@usp.br

Received for publication on June 21, 2006.

Accepted for publication on August 29, 2006. teoporosis, falls can result in hip fracture, possibly the most disastrous accidental episode among the elderly. ${ }^{3}$ Recently reported data suggest that 1 out of every 15 older people with hip fracture will die while hospitalized, and over $30 \%$ of those discharged will die within the year following the fracture. ${ }^{4}$

Falls are considered the main cause of death by accident in people aged 65 years and over. ${ }^{5}$ About one third of the individuals in this age group living in the community will fall each year ${ }^{6}$ and the incidence rises to $50 \%$ in individuals aged 80 and over. ${ }^{7,8}$

The fear of falling and its direct relationship with the restriction of daily living and social activities account for the most important psychological changes secondary to falls among the elderly. ${ }^{9}$

A cohort study in 1667 people aged 65 and over ${ }^{10}$ identified factors related to falls, such as previous fractures, female sex, sight problems, and difficulty in performing ADLs. 
Physical and functional consequences of a fall include proximal fractures of the femur (mainly cervical or trochanteric), soft tissue traumas, walking disability, inability to perform daily activities, functional morbidity, fear of falling, and institutionalization. These events are related to high mortality and significant limitation, ${ }^{11}$ mainly after 75 years of age. ${ }^{12,13}$

The general objective of this study was to investigate the functional evolution of elderly individuals with hip fracture in the year following the fracture. The specific objectives were to identify the factors associated with functional ability prior to the hip fracture and in the year following the fall and to quantify the mortality in this elderly age group.

\section{METHOD}

A retrospective descriptive study with elderly patients (aged 60 years and over) admitted during 2000 with hip fracture secondary to a fall was performed.

Once the study was approved by the Ethics Committee, patients were contacted by phone or mail, after which they were informed about the purpose of the study, and an outpatient visit was scheduled. Patients were advised to bring an escort or caregiver with them.

When patients were not able to walk or be transported to the service, a home visit was scheduled, duly authorized by the patient or his or her legal guardian, in order to proceed with an interview. The same procedure was adopted for a single patient who had been institutionalized after the fracture.

Patients deceased after hospital discharge were identified, and their relatives or guardians were interviewed by phone or at home (with due authorization) to provide information about the social, demographic, and functional conditions of the patient prior to the fall and about the survival period following the fracture.

The study did not include data from patients who did not live in Sao Paulo city, nor when patients or their relatives failed to provide sufficient information. The total number of patients included in the study was established after determining whether the general data was accessible in the hospital archive.

The anamnesis interview was performed with the purpose of gathering information to provide an epidemiological profile of the hip fracture as well as possible associated factors including aspects of personal and hospitalization data, history of the fall and fracture, living conditions, and physical evaluation. An investigation was made for presence or absence of preexisting fractures, the walking status, and functional ability before and 1 year after the fracture, using Katz's Index ${ }^{14}$ and Lawton's Index ${ }^{15}$ regarding the so-called instrumental ADLs.

For patients with cognitive deficit (dementia or mental confusion), relatives or caregivers were interviewed. The same procedure was adopted for patients who had died or were institutionalized. After the data collection, we started the statistical process to verify the influence of evaluated factors on the functional evolution of elderly patients interned for hip fracture secondary to a fall. We used the nonparametric McNemar and Wilcoxon tests to evaluate qualitative data of results obtained before and after the fracture, the paired $t$ test to evaluate results of Katz's Index and Lawton's Index before and after the fracture, and logistic regression, all with a 5\% descriptive level, using SPSS 8.0 for Windows and MINITAB 13 for Windows.

\section{RESULTS}

Between January $1^{\text {st }}$ and December $31,2000,62$ patients aged over 60 years and with hip fracture secondary to a fall were selected. The medical records of 6 patients out of 62 were not located; therefore, the initial study population included 56 patients, (Table 1). We experienced data loses due to medical records that could not be found (6), medical records with insufficient data (12); moving to a different town (4), refusal to participate, and (2), death during hospitalization (4). Thirty-four patients (29 men and 5 women) completed all the data of the interview. Most women were widows $(76 \%)$ and $18 \%$ were married. Regarding men, $56 \%$ were married and $33 \%$ were widowers.

Table 1 - General Data

\begin{tabular}{lcccc}
\hline Patients & $\begin{array}{c}\text { Number } \\
(\%)\end{array}$ & $\begin{array}{c}\text { Stay } \\
(\text { days })\end{array}$ & $\begin{array}{c}\text { Age } \\
(\text { years })\end{array}$ & $\begin{array}{c}\text { Mortality } \\
\text { in 1 year }\end{array}$ \\
\hline Men & $47(84 \%)$ & 15 & $80(60-93)$ & 67 \\
Women & $09(16 \%)$ & 11 & $80(62-100)$ & 23 \\
\hline
\end{tabular}

Concerning ethnicity, $91 \%$ of the elderly were considered Caucasians, $1.8 \%$ black, $1.8 \%$ mulattoes, and $5.4 \%$ Asians.

Transtrochanteric fractures were the most commonly found ( $45 \%$ of cases), followed by cervical femoral $(38 \%)$, and subtrochanteric fractures $(7.3 \%)$.

Most of these elderly patients underwent osteosynthesis $(59 \%) ; 27 \%$ underwent partial hip arthroplasty, and $14 \%$ were treated conservatively. Mortality was not associated with the type of fracture $(P=0.72)$ or treatment $(P=0.11)$.

Four $(6.5 \%)$ of the 62 patients died in hospital. General mortality in the following 6 months was $16 \%$, and at 1 year following the fracture it was $30 \%$. Mortality among women was $23 \%$ and $67 \%$ among men. Mortality was as- 
sociated with sex $(P=0.015)$ and age $(P=0.05)$. The odds ratio for a man to die as compared with women was 4.0 (95\% confidence interval, 1.3-27).

As regards mortality per age group, $71 \%$ of deaths occurred in subjects over 80 years (12 deaths among 30 subjects of this age group) while $29 \%$ of deaths occurred in patients aged between 60 and 80 years ( 5 deaths among 26 patients in this age group). Patients aged over 80 years were more likely to die as compared with individuals in the 60-80 year age group $(P=0.001$; odds ratio $=3.2$ with $95 \% \mathrm{CI}, 1.0-11)$.

Concerning the fall, we observed that the period of the day with highest incidence was the morning $(40 \%)$, then the afternoon (26\%), night (26\%), and early morning $(7.1 \%$.) Table 2 shows the more prevalent places for falls.

Table 2 - Distribution of patients according to place of fall

\begin{tabular}{lcc}
\hline Place of fall & Number of subjects & $\%$ \\
\hline bathroom & 3 & 7.7 \\
corridor & 1 & 2.7 \\
bedroom & 11 & 28 \\
living room & 4 & 10 \\
kitchen & 6 & 15 \\
Stairs & 6 & 15 \\
backyard & 2 & 5.1 \\
Street & 4 & 10 \\
hospital room & 2 & 5.1 \\
Total & 39 & $100 \%$ \\
\hline
\end{tabular}

Over the 1 year period prior to the fracture, $52 \%$ of patients had suffered falls and $21 \%$ had fractured their hips. In the year following the fracture, $34 \%$ of patients fell again, but only $6.3 \%$ experienced a new hip fracture.

The walking condition prior to the fracture was preserved in $97 \%$ of the interviewed patients; $76 \%$ of them walked inside and outside their homes, 33\% walked with the aid of a walking device such as a walking cane or a walker, $24 \%$ walked inside the house only, and $27 \%$ experienced pain while walking.

Among those who walked prior to the fracture, $36 \%$ were not walking in the year following the fracture. Of these, $90 \%$ required a supporting device, $52 \%$ walked inside the house only, and $57 \%$ experienced pain while walking.

Only $6.1 \%$ of patients practiced regular physical activity prior to the fracture, and this percentage was reduced to $3.2 \%$ after the fracture.

Prior to the fracture, $32 \%$ of patients lived with a son or daughter, $21 \%$ lived with a spouse, and $17.7 \%$ lived with daughter-in-law or son-in-law and grandchildren. Most patients $(82 \%)$ continued to adopt the same household conditions after hospital discharge. One female patient was institutionalized after hospital discharge, and 2 went to live with a full-time caregiver.
Prior to the fracture, $45 \%$ of the patients reported visual difficulties. After the fracture, 59\% patients reported that they could not see well. There was no relationship between falls and visual acuity after the fracture $(P=0.070)$, and there was no association between the awareness of seeing well and the walking condition 1 year following the fracture $(P=0.302)$.

The existing diseases at the time of fracture and the number of diseases per patient are shown in Tables 3 and 4 .

Both ADLs and IADLs experienced important reductions after the fracture, with decreased ability and increased dependence of the patients in the year after that (Tables 5 and 6).

Table 3 - Preexisting diseases

\begin{tabular}{lcc}
\hline Preexisting disease & Before hip fracture $(\mathrm{n}=53)$ & $\%$ \\
\hline Osteoporosis & 10 & $19 \%$ \\
Arterial hypertension & 36 & $68 \%$ \\
Diabetes & 18 & $34 \%$ \\
Stroke & 5 & 9.4 \\
Dementia & 7 & $13 \%$ \\
Cataract & 8 & $15 \%$ \\
Coronary insufficiency & 12 & $23 \%$ \\
Heart failure & 5 & $9.4 \%$ \\
Urinary incontinence & 5 & $9.4 \%$ \\
Anemia & 4 & $7.6 \%$ \\
Arthritis & 7 & $13 \%$ \\
Cancer & 6 & $11 \%$ \\
\hline
\end{tabular}

Table 4 - Number of preexisting diseases per patient

\begin{tabular}{lcc}
\hline Number of diseases & Number of patients & $\%$ \\
\hline 1 & 7 & $13 \%$ \\
2 & 11 & $21 \%$ \\
3 & 13 & $25 \%$ \\
4 & 12 & $23 \%$ \\
5 & 3 & $5.7 \%$ \\
6 & 4 & $7.6 \%$ \\
7 & 3 & $5.7 \%$ \\
Total & 53 & $100 \%$ \\
\hline
\end{tabular}

\section{DISCUSSION}

Initially, it is important to consider the data loss existing in our retrospective study. Although regrettable, this situation results from the logistic limitations of conducting retrospective studies based on medical records not necessarily designed to answer the questions of a research protocol. Although it is expected that the implementation of electronic medical records will improve this situation, it is obvious that prospective studies where data are obtained in the desired design, limiting this bias, are really beneficial.

The distribution of our cases with regard to sex, race, ${ }^{16}$ marital status, ${ }^{17}$ place of fall, ${ }^{18}$ type of fracture and treat- 
Table 5 - ADL in patients before and after hip fracture

\begin{tabular}{|c|c|c|c|c|c|c|}
\hline ADL & & YES & $\%$ & NO & $\%$ & $\mathrm{P}$ \\
\hline \multirow[t]{2}{*}{ Bathing } & Before & 23 & $70 \%$ & 10 & $30 \%$ & 0.004 \\
\hline & After & 14 & $45 \%$ & 17 & $55 \%$ & \\
\hline \multirow[t]{2}{*}{ Dressing } & Before & 27 & $82 \%$ & 6 & $18 \%$ & 0.01 \\
\hline & After & 16 & $52 \%$ & 15 & $48 \%$ & \\
\hline \multirow[t]{2}{*}{ Toilet } & Before & 27 & $82 \%$ & 6 & $18 \%$ & 0.001 \\
\hline & After & 16 & $52 \%$ & 15 & $48 \%$ & \\
\hline \multirow[t]{2}{*}{ Physical Ambulation } & Before & 29 & $88 \%$ & 4 & $12 \%$ & 0.001 \\
\hline & After & 17 & $55 \%$ & 14 & $45 \%$ & \\
\hline \multirow[t]{2}{*}{ Urinary/faecal Continence } & Before & 21 & $64 \%$ & 12 & $36 \%$ & 0.001 \\
\hline & After & 10 & $32 \%$ & 21 & $68 \%$ & \\
\hline \multirow[t]{2}{*}{ Feeding } & Before & 30 & $91 \%$ & 3 & $9.0 \%$ & 0.016 \\
\hline & After & 23 & $74 \%$ & 8 & $26 \%$ & \\
\hline
\end{tabular}

Table 6 - IADL in patients before and after hip fracture

\begin{tabular}{|c|c|c|c|c|c|c|}
\hline IADL & & YES & $\%$ & NO & $\%$ & $\mathrm{P}$ \\
\hline \multirow[t]{2}{*}{ Telephone } & Before & 17 & $52 \%$ & 16 & $48 \%$ & 0.025 \\
\hline & After & 11 & $35 \%$ & 20 & $66 \%$ & \\
\hline \multirow[t]{2}{*}{ Shopping } & Before & 10 & $30 \%$ & 23 & $70 \%$ & 0.005 \\
\hline & After & 2 & $6 \%$ & 29 & $94 \%$ & \\
\hline \multirow[t]{2}{*}{ Meal preparation } & Before & 14 & $42 \%$ & 19 & $58 \%$ & 0.025 \\
\hline & After & 9 & $29 \%$ & 22 & $61 \%$ & \\
\hline \multirow[t]{2}{*}{ Housekeeping } & Before & 24 & $73 \%$ & 9 & $27 \%$ & 0.003 \\
\hline & After & 13 & $42 \%$ & 18 & $58 \%$ & \\
\hline \multirow[t]{2}{*}{ Laundry } & Before & 20 & $61 \%$ & 13 & $39 \%$ & 0.025 \\
\hline & After & 14 & $45 \%$ & 17 & $55 \%$ & \\
\hline \multirow[t]{2}{*}{ Transport } & Before & 13 & $39 \%$ & 20 & $61 \%$ & 0.008 \\
\hline & After & 6 & $19 \%$ & 25 & $81 \%$ & \\
\hline \multirow[t]{2}{*}{ Medications } & Before & 14 & $42 \%$ & 19 & $58 \%$ & NS \\
\hline & After & 11 & $35 \%$ & 20 & $65 \%$ & \\
\hline \multirow[t]{2}{*}{ Finances } & Before & 19 & $58 \%$ & 14 & $42 \%$ & 0.008 \\
\hline & After & 12 & $39 \%$ & 19 & $61 \%$ & \\
\hline
\end{tabular}

ment, time of hospitalization, ${ }^{19}$ hospital mortality at 6 months and 1 year, ${ }^{3,20}$ as well as higher mortality among the very elderly ${ }^{3,16}$ agreed with the data reported from other countries, including recent references of cohort studies with large numbers of cases. ${ }^{3}$

Worth noting is the high average age of the patients studied (79 years). This spefific aspect is related to the differentiated submission of complex cases to high resolution hospitals, and certainly reflects on the overall mortality rate, causing it to be high merely on account of the higher mortality in older patients; this applies to our study and to the study by Jiang et al who studied a very elderly population with an in-hospital mortality index of 6.3\% and 1-year mortality of $30.2 \% .^{3}$ Another characteristic is the high number of associated affections: $42 \%$ of patients presented 4 or more diseases. In such a situation, one may say that hip fracture often is an epiphenomenon that is more related to the extreme frailness of the elderly than to being a real disease. The cause of deaths in these patients often is much more related with concomitant diseases such as bronchopneumonia, heart failure, or stroke ${ }^{21}$ than with the fracture in itself.
The fact that the type of fracture or treatment did not influence mortality in our series of cases reinforces this concept.

On the other hand, the advanced age of our group could be related to findings that do not agree with those from the literature ${ }^{22}$ such as the lack of relationship between falls and visual acuity after the fracture and the lack of significant association between the awareness of seeing well and the walking condition 1 year following the fracture.

The history of fall is an indicator of a new episode, as happened with more than half of our patients. The most common place for accidental fall is home, possibly due to the age limitation itself, although $75 \%$ of patients reported walking inside and outside the house prior to the fall. Since the risk of falling in the streets is more obvious, it is possible that individuals are more careful under these conditions than inside their homes where they believe safety to be on a higher level. It is worth emphasizing in this situation the importance of evaluating and correcting environmental risks, particularly among the very elderly.

In this study we observed that the great majority of patients did not practice regular physical activities prior to 
fracture (94\%) and following it (97\%). Low activity, considered a cause and effect of the frailness of the very elderly, seems to be significantly related to the risk for fracture, thus identifying possible actions of prevention in this age group. The even more pronounced reduction of physical activity in the postfracture period might be related to development of fear of falling that is so common among these patients an is also associated as cause and effect of the accelerated muscle wasting observed in the very inactive elderly. ${ }^{23}$ In support of this possibility, we found a significant reduction in the walking condition after the fracture, and a significant increase of the dependence on the walking supporting device after the fracture.

Regarding functional ability, a significant reduction in the ability to perform basic and instrumental activities of daily living prior to fracture and in the year following it was found after the fracture. This occurrence is frequently reported in literature both in terms of reduction in ability to perform instrumental activities of daily living related to higher risk for fracture ${ }^{24}$ and of the association between fracture and later worsening in the functional performance. ${ }^{25,26}$ The significant decrease in the abilities related to functional capacity in our patients was worse for men than for women.

\section{CONCLUSION}

The evolution of the elderly patients in the first year after hip fracture exhibits, aside the high mortality rate, an important reduction of functional ability parameters as measured by instruments such as the ADLS and IADLS scales. The worse functional status was associated with factors such as age, mainly in the called very-old group ( $>80$ years) and male sex. These factors might be seen as markers that could indicate the need for special care in these patients with the aim of reducing the health risk linked to hip fracture and its treatment.

\section{RESUMO}

Garcia R, Leme MD, Garcez-Leme LE. Evolução de idosos brasileiros com fratura de colo de femur secundária à queda. Clinics. 2006;61(6):539-44.

OBJETIVO: Estudar o perfil epidemiológico, mortalidade e a evolução funcional, no primeiro ano após a fratura, de idosos com fratura de quadril visando a contribuir para a prevenção de quedas.

CASUÍSTICA E MÉTODO: Foram estudados 56 pacientes idosos, com 60 anos ou mais, com fratura de quadril decorrente de queda, internados em 2000. Alem dos dados de prontuário, os pacientes ou responsáveis responderam a um questionário, fornecendo informações sobre os dados pessoais, história da queda e da fratura, avaliação física e da capacidade para realização de atividades de vida diárias básicas e instrumentais antes e após um ano da ocorrência da fratura, através dos índices de Katz e de Lawton, respectivamente.
RESULTADOS: Observou-se que as fraturas foram mais comuns em mulheres, brancas, viúvas e que a maioria das quedas ocorreu no domicílio. A mortalidade geral após um ano da ocorrência da fratura foi de $30,35 \%$, e associou-se o sexo e idade. Houve aumento de incapacidade para deambular e de utilização de dispositivo de apoio. Houve redução significativa da capacidade funcional para realização das atividades de vida diárias básicas e instrumentais.

CONCLUSÃO: A evolução da fratura do quadril no primeiro ano está relacionada a alta mortalidade e queda da capacidade funcional; idade e o sexo masculino são fatores indicadores de pior prognóstico ressaltando a necessidade do acompanhamento especial destes pacientes no pós-operatório imediato e tardio.

UNITERMOS: Idoso. Fratura de quadril. Quedas. Capacidade funcional. AVD. 
1. Tinetti ME, Williams TF, Mayewski R. Fall risk index for elderly patients based on number of chronic disabilities. Am J Med. 1986;80:429-34.

2. Beaupre LA, Johnston DWC, Majumdar SR, Jones CA, Buckingham J, Saunders LD. State of the science review: Continuum of care and integration of services for treatment of elderly patients with hip fracture. Alberta Heritage Foundation for Medical Research and Alberta Ministry of Health and Wellness Technical Report. 2003. Available online at http:/ /www.ahfmr.ab.ca/grants/state_of_science_final_reports.php. Accessed on September 8, 2005.

3. Szulc P, Duboeuf F, Schott AM, Dargent-Molina P, Meunier PJ, Delmas PD. Related articles, Structural determinants of hip fracture in elderly women: re-analysis of the data from the EPIDOS study. Osteoporos Int. 2005 Jun 28.

4. Jiang HX, Majumdar SR, Dick DA, Moreau M, Raso J, Otto DD, et al. Development and initial validation of a risk score for predicting inhospital and 1-year mortality in patients with hip fractures. J Bone Miner Res. 2005;Mar;20:494-500.

5. National Safety Council. National Safety Council Accidental Facts. Chicago: National Safety Council, 1988.

6. Campbell AJ, Robertson MC, Gardner MM, Norton RN, Tilyard MW, Buchner DM. Randomised controlled trial of a general practice programme of home based exercise to prevent falls in elderly women. BMJ. 1997;315:1065-9.

7. Alexander NB. Postural control in older adults. J Am Geriatr Soc. 1994;42:93-108.

8. Tinetti ME, Baker DI, McAvay MSG, Clauss EB, Garrett P, Gottschalk $\mathrm{M}$, et al. A multifactorial intervention to reduce the risk of falling among elderly people living in the community. New England J. Med. 1994;331:821-7.

9. Luukinen H, Koski K, Laippala P, Kivela SL. Factors predicting fractures during falling impacts among home-dwelling older adults. J Am Geriatr Soc. 1997;45:1302-9.

10. Perracini MR. Fatores associados a quedas em uma coorte de idosos residentes no município de São Paulo, 2000. Thesis presented for Doctor's Degree to Escola Paulista de Medicina.

11. Sosa MH, Segarra MCS, Liminana JMC, Hernandez DH, Gonzalez AP, Betancor PL. Morbidity and mortality of osteoporotic proximal femoral fracture after one year follow-up. Med Clin (Barc). 1993;101:481-3.

12. Tonetti J,Couturier P, Remy A, Nicolas L, Merloz P, Franco A. Proximal femoral fractures in patients over 75 years. Vital and functional prognosis of a cohort of 78 patients followed during 2.5 years. Rev Chir Orthop Reparatrice Appar Mot. 1997;83:636-44.

13. Cree M, Carriere KC, Soskolne CL; Suarez-Almazor M. Functional dependence after hip fracture. Am J Phys Med Rehabil. 2001;80:73643.
14. Katz S. Assessing self-maintenance: activities of daily living, mobility, and instrumental activities of daily living. J Am Geriatr Soc. $1983 ; 31: 721-7$

15. Lawton MP, Brody EM. Assessment of older people: self-maintaining and instrumental activities of daily living. Gerontologist. 1969;9:17986.

16. Villas-Boas AJ, Vercesi AE, Bodachne L, Vialle LRG. Estudo epidemiológico de fraturas de fêmur proximal em idosos. Acta Ortop Bras. 1996;4:122-6.

17. The Staff of the Benjamin Rose Hospital: Multidisciplinary study of Illness of aged persons. II. A New Classification of Functional Status in Activities of Daily Living. J Chron Dis. 1959;9:55-62.

18. Norton R, Campbell AJ, Lee-Joe T, Robinson E, Butler M Circumstances of falls resulting in hip fractures among older people. $\mathrm{J}$ Am Geriatr Soc. 1997;45:1108-12.

19. Vega EM Mautalen CA, Carrilero P, Wittich A, Sahores AO, Silberman FS. Factores de riesgo, densidad mineral osea, composición corporal y alteraciones bioquímicas en pacientes y controles de similar edad. MEDICINA (Buenos Aires) 1996;56:353-62.

20. Rose S, Maffulli N. Hip fractures. An epidemiological review. Bull Hosp Jt Dis. 1999;58:197-201.

21. Ira P, Scott DL, O'Neill TW, Pritchard C, Woolf AD, Davis MJ. Quality of life, morbidity and mortality after low trauma hip fracture in men. Ann Rheum Dis. 2006;65;87-92.

22. Dargent-Molina P, Favier F, Grandjean H, Baudoin C, Schott AM, Hausherr E et al. Fall-related factors and risk of hip fracture: the EPIDOS prospective study. Lancet. 1996;348:145-9. Erratum in: Lancet 1996;348:416.

23. Volpi E, Nazemi R, Fujita S. Muscle tissue changes with aging. Curr Opin Clin Nutr Metab Care. 2004;7:405-10.

24. Covinsky KE, Palmer RM, Counsell SR, Pine ZM, Walter LC, Chren MM. Functional status before hospitalization in acutely ill older adults: validity and clinical importance of retrospective reports. J Am Geriatr Soc. 2000;48:164-9.

25. Espino DV, Palmer RF, Miles TP, Mouton CP, Wood RC, Bayne NS, et al. Prevalence, incidence, and risk factors associated with hip fractures in community-dwelling older Mexican Americans: results of the Hispanic EPESE study. J Am Geriatr Soc. 2000;48:1252-60.

26. Furlaneto ME, Garcez-Leme LE. Delirium in elderly individuals with hip fracture: causes, incidence, prevalence, and risk factors. Clinics. 2006;61:35-40 